\title{
SYNTHETIC APERTURE RADAR FOR GEOLOGICAL APPLICATIONS IN THE MOIST TROPICS: EXPERIENCES FROM THE BRAZILIAN AMAZON REGION
}

\author{
WALDIR RENATO PARADELLA, ATHOS RIBEIRO DOS SANTOS, PAULO VENEZIANI \\ AND MARIA CAROLINA DE MORAIS
}

\begin{abstract}
A reasonable amount of airborne and orbital Synthetic Aperture Radar (SAR) data, with distinct characteristics (frequency, polarization, viewing terrain geometry, resolution, etc.), has been acquired over the Amazon Region during the last decade. As the region is involved in rain, cloud, haze and smoke, SAR images are invaluable in providing geological information due the enhancement of the terrain caused by the side-viewing geometry, and the all-weather sensing capability. In this paper, we discuss the effects of the sensor/terrain variables on geological mapping and exploration using C-band SAR examples from the Tapajós National Forest and Carajds Province. The experience with this kind of remote sensing data in the tropics has shown that an effective applicability of the technology is obtained when a consistent background in SAR imagery, digital image processing and photointerpreter's skill are taken into account in the approach.
\end{abstract}

keywords: radar, geology, Carajás Mineral Province, Tapajós National Forest, Amazon Region.

BACKGROUND Distinct from the optical sensors which use the reflected sunlight to provide information about the chemical composition and physical structure of a surface, imaging radar provides information about the terrain's geometry and electrical properties by detecting the backscattered field of active microwave energy (Elachi 1987).

Geoscientists should be aware of the differences in relation to optical images when dealing with a SAR image. Both system parameters (wavelength, polarization, and viewing geometry) and terrain parameters (roughness, complex dielectric constant, shape, orientation) influence the image's appearance. The quality of interpretation improves with the comprehension of SAR fundamentals, the region under investigation and the application involved. The greater the knowledge of all of these related topics, the more consistent and reliable the interpretation will be (Lewis et al. 1998).

When a radar beam strikes a surface, it is reflected, absorbed, and transmitted. Reflections occur when a discontinuity in the dielectric constant occurs at the surface. An increase in water content will affect the dieletric properties of vegetation and result in decreased transmission and increased extinction (reflection plus absorption) of microwave energy in forests. The radar backscatter from closed forests is mainly controlled by volume scattering in the interior of the vegetation layer. Soil/rock surface scattering occur when the radar beam either directly or indirectly strikes the soil surface under the forest. Microwaves also have the ability to penetrate a vegetation canopy deeper than optical wavelengths can. The penetration is determined by the vegetation's (moisture content and density) and the sensor's (wavelength and viewing geometry) characteristics. For a Cband SAR, sources of backscatter are related to leaves, twigs, and secondary branches, and are concentrated in the upper parts of the forest (van der Sanden 1997).

Three scales of sensor/terrain roughness can be considered when dealing with a radar interpretation: microscale, mesoscale and macroscale roughness (Lewis et al. 1998). Microscale roughness is the roughness on the scale of fractions of the wavelength and strongly determines the image tone. In a vegetated terrain, leaf parameters (number, size, area, etc.) are the main control of image tones. If the terrain is not completely covered by vegetation, the ground roughness (rocks, soils, etc.) will contribute to the microscale roughness. Mesoscale roughness is the "gross roughness envelop" and controls the image texture (spatial arrangement of tone). For a vegetated terrain, it is the roughness of the vegetation canopy on a scale larger than the spatial resolution cell. Finally, macroscale roughness is controlled by changes in the macro-topography (slopes, tilts, broad undulations in the terrain), and is related to structures and geomorphology (macrotexture patterns many times larger than the resolution cell). Obviously, the sensor's resolution plays an important role in the image's texture. However, two important factors, which affect the information content of the images, are the look-azimuth and the incident angle. These factors will be addressed in detail.

STUDY SITES Two areas, representing distinct terrain types in
Amazon region, were selected:

Tapajós National Forest and Carajás Province (fig. 1). The Tapajós National Forest is characterized by a low terrain rolling relief (altitudes less than 100 meters), sub-divided into the lower Amazon and the higher Xingu-Tapajós Plateaus. The vegetation is typical of the dense tropical forest showing high plateaus with emergent and uniform cover, and low and dissected plateaus with emergents and open tropical forest (Shimabukuru et al. 1998). Geologically, the area is within the Amazon Sedimentary Basin, with fluvial to lacustrine sediments of the Alter do Chao Formation, part of the Javari Group, with Tertiary age (Torres 1998).

The Carajás Province, which hosts the world's largest iron deposits, is part of the Amazonian Craton. It is characterized by a set of hills and plateaus (altitudes around 750 meters), surrounded by southern and northern lowlands (altitudes around 250 meters), covered by Ombrophilous Equatorial forest (Paradella et al. 1994). The area is part of the Archean Itacaiunas Shear Belt, and has been sub-divided into a Basal Assemblage, with ductile shearing, high grade metamorphism rocks, and a Cover Assemblage, represented by low- to very low-grade volcanic and sedimentary rocks preserved along the Carajás Strike-Slip and Cinzento Strike-Slip Systems (Pinheiro 1997).

DATASET A data collection from distinct sources was used in the study. The airborne SAR image from Carajás was acquired in 1992 during the SAREX' 92 campaign, and is related to the CCRS (Canada Centre for Remote Sensing) Convair 580. In addition, a Landsat TM data was also acquired in 1992 under the same experiment. The RADARSAT images for both study sites were acquired in 1996, as part of ADRO program. Finally, the airborne gamma ray Total Count (TC) channel was collected in 1975, and was provided by Brazilian Geological Survey (Paradella et al. 1997). Table 1 provides the characteristics of the remotely-sensed data used in the investigation.

VIEWING GEOMETRY The Look Azimuth At equatorial latitudes, RADARS AT-1 look-azimuth is constant at $78^{\circ}$ azimuth for

Table 1. Characteristics of the remotely-sensed data

\begin{tabular}{|c|c|c|c|c|c|}
\hline Patform & Sensior & $\begin{array}{l}\text { Acquisilition } \\
\text { Dathe and Site }\end{array}$ & $\begin{array}{l}\text { Incident Angle } \\
\text { (deb) }\end{array}$ & $\begin{array}{c}\text { Spatiol } \\
\text { Resolution (m) }\end{array}$ & $\begin{array}{c}\text { Illumination } \\
\text { Geumntry }\end{array}$ \\
\hline $\begin{array}{c}\text { CCRS } \\
\text { Convair 580 }\end{array}$ & $\begin{array}{l}\text { SAR-C } \\
\text { Whic } \\
\text { Mude }\end{array}$ & $\begin{array}{l}\text { April 15. 1992, } \\
\text { Carajas }\end{array}$ & $45^{\circ} / 85^{4}$ & $18.7 \times 9.8$ & $\begin{array}{c}\text { Look } \\
\text { Arimul| }=282^{\circ}\end{array}$ \\
\hline RADARSAT +1 & $\begin{array}{l}\text { Standind } \\
\text { Mode } \\
\text { Beam } 5\end{array}$ & $\begin{array}{c}\text { May 31, 1996, } \\
\text { Carajas }\end{array}$ & $35^{\circ} / 42^{\nu}$ & $24.2 \times 27$ & $\begin{array}{c}\text { Look Azimulh = } \\
282^{\circ}\end{array}$ \\
\hline RADARSAT.I & $\begin{array}{l}\text { Standard } \\
\text { Mode } \\
\text { Bcam } 6\end{array}$ & $\begin{array}{l}\text { Nowember 28, } \\
1996, \text { Carajsas }\end{array}$ & $41^{\circ} / 46^{\prime \prime}$ & $22.1 \times 27$ & $\begin{array}{c}\text { Look Adimuth }= \\
78^{\circ}\end{array}$ \\
\hline RADARSAT-1 & $\begin{array}{l}\text { Standaru } \\
\text { Merte } \\
\text { Beam } 2\end{array}$ & $\begin{array}{c}\text { August 10, } \\
\text { 1996, Tupajos }\end{array}$ & $24^{\prime \prime} / 3 \mathrm{~b}$ & $22 \times 2 \mathrm{~T}$ & $\begin{array}{c}\text { Luok Aximulh = } \\
2 x 2^{* *}\end{array}$ \\
\hline RADARSAT-I & $\begin{array}{l}\text { Slandard } \\
\text { Mode } \\
\text { Bcain } 7\end{array}$ & $\begin{array}{l}\text { December } 5 \\
\text { 19\%, Tapajos }\end{array}$ & $45^{\circ} / 49^{\circ}$ & $20.199 \times 27$ & $\begin{array}{c}\text { Lok Arimulh }= \\
282^{\prime \prime}\end{array}$ \\
\hline EANDSAT 5 & $\begin{array}{l}\text { Thematic } \\
\text { Mapner } \\
\text { Bams } 4\end{array}$ & $\begin{array}{c}\text { June } 22,1992, \\
\text { Carajass }\end{array}$ & n.m.r. & $30 \times 34$ & $\begin{array}{c}\text { Sun Azimuth = } \\
4 y^{\circ} \\
\text { Sun Elcvation = } \\
43^{*}\end{array}$ \\
\hline
\end{tabular}




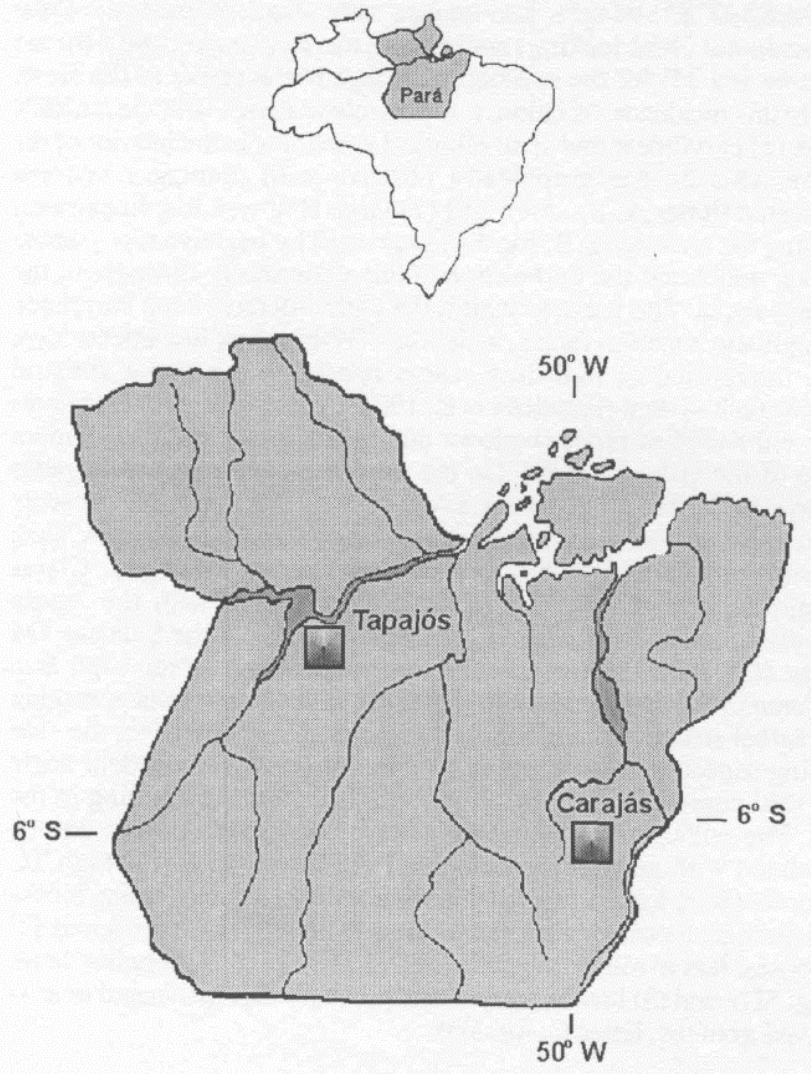

Figure 1. Test sites location.

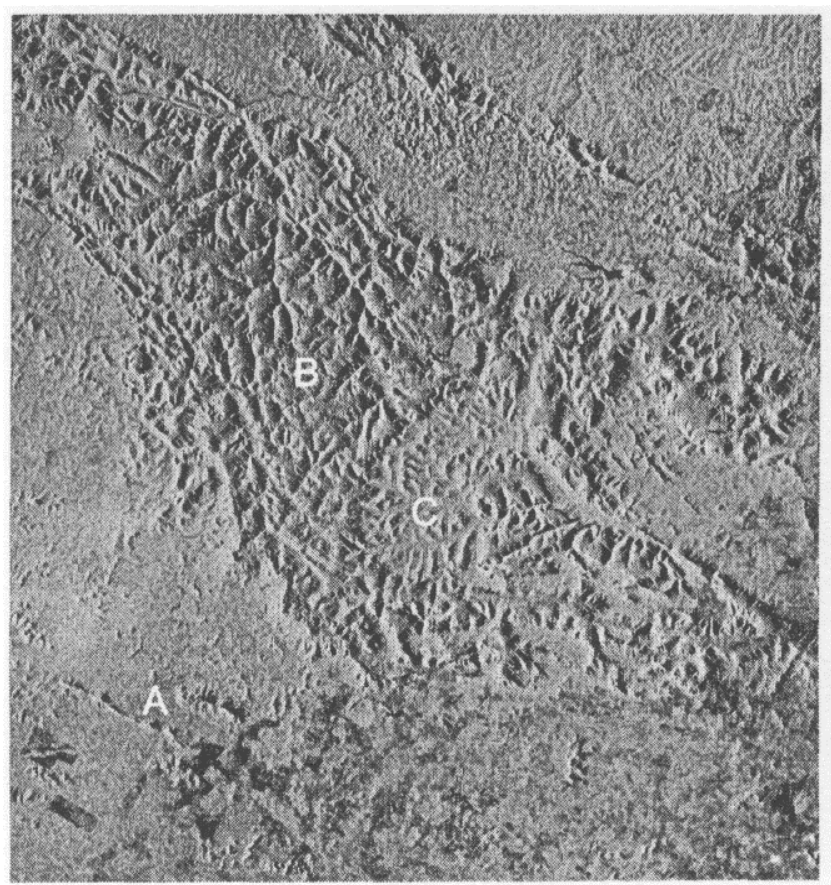

(A)

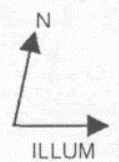

ascending passes, and $282^{\circ}$ azimuth for descending passes. For a given look-azimuth, structural trends normal to the illumination will be highlighted while topographic features within about $20^{\circ}$ of the look direction can be invisible (Lowman Jr. 1987). Two images taken from opposite-look directions often contain complementary geological information. These effects are illustrated in Figure 2 based on two RADARSAT Standard (S) images from Carajás. The ascending S6 is better than the descending $\mathrm{S} 5$ image in the detection of the main geological structures in the Province, which are mainly oriented to N60-70W (more favorable look-direction with the ascending pass). Rocks from the Basal Assemblage (mainly Xingu Complex) are more detectable in the ascending imagery (letter A, Fig. 2A). For the Carajás Strike-Slip System, the ascending pass, with a more orthogonal viewing to the local slope than the descending ones, provides a superior rendition of the topographic relief related to the Aguas Claras Formation and the Central granite (letters B and C, Fig. 2A ). To the north, the Cinzento Strike-Slip system is clearly well-defined in the ascending image, and is partly not apparent in the descending scene (letter A, Fig. 2B). However, descending imagery is important in the better enhancement of NE and NS structures along the Carajás StrikeSlip System (letters B and C, Fig. 2B), and has presented an important advantage for visual analysis: the absence of relief inversion. The ascending/descending Standard pair has provided complementary geological information and reinforce the importance of using radar in the tropics with opposite look-directions (Paradella et al. 1997, Paradella et al. 2000).

The Incident Angle Radar backscatter is strongly affected by slope effects at small incident angle from 0 to $30^{\circ}$, by surface roughness at moderate incident angle from 30 to $70 \mathrm{o}$, and mainly by shadowing at high incident angle from 70 to $90^{\circ}$ (JPL 1980). This means that low local slopes modulate radar backscatter at low inicident angle and enhance topography in a way comparable to shadowing, which enhances landform under high incident angles (Ford et al 1998). Forest canopies are the primarily volume scatters for a rainforest terrain and modulate the surface roughness expressed as distinct image texture. Thus, a large variability of incident angle is necessary for maximum

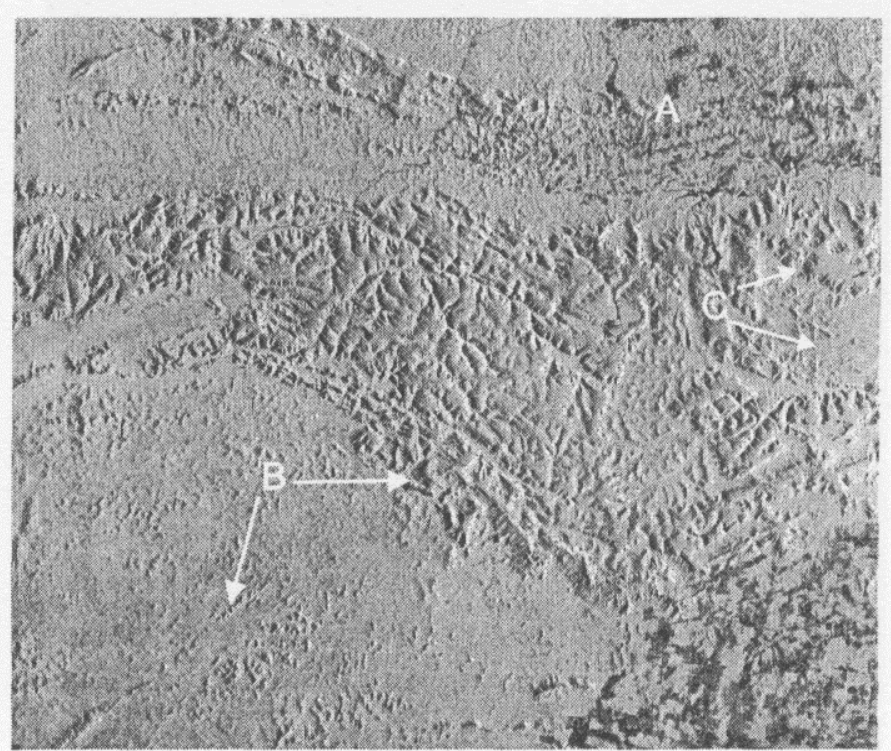

(B)

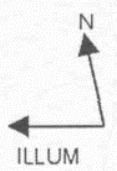




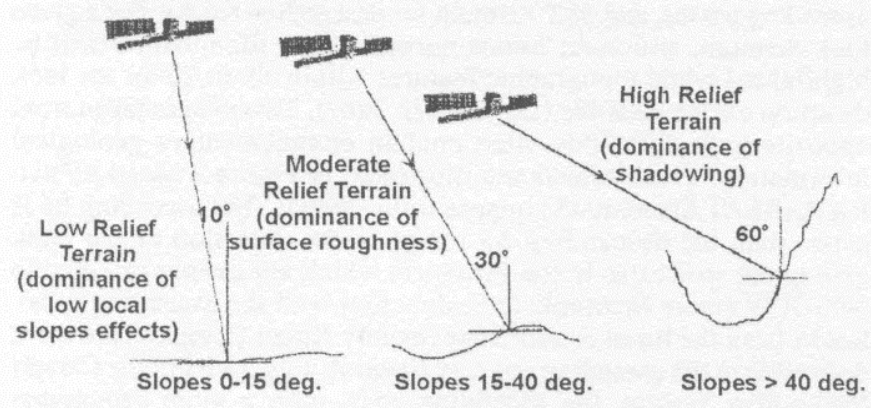

Figure 3. A general model relating optimal incidence, surface morphology and SAR backscatter controls (adapted from Singhroy \& St-Jean 1999).

effectiveness in geological applications.

RADARSAT-1 offers 35 distinct beam-mode combinations, with incident angles varying from 10 to $59^{\circ}$. A model that can be used as guideline for the selection of the optimal incidence with these data is presented in figure 3. Figure 4 shows a comparison of two Standard descending images (S2, S7) collected over the Tapajós National Forest. The S2 image with steeper viewing geometry (incidence range: $24-31^{\circ}$ ) provides a better enhancement of the surface morphology in this low relief terrain, particularly in the near range of the image (letters A, fig. 4A). Minor topographic breaks, associated with drainages, slopes, and erosional features within the dissected plateaus, are more detected in the S2 image than in the S7 (incident range: 45-49 o ). While S2 provides a better enhancement of the morphology (low local slope), S7 image expresses the overall surface roughness related to the relatively uniform canopies of the rainforest (letter A, fig 4B).

Figure 5 shows examples of prominent geological features in the Central Serra dos Carajás Granite area using two SAR (SAREX and

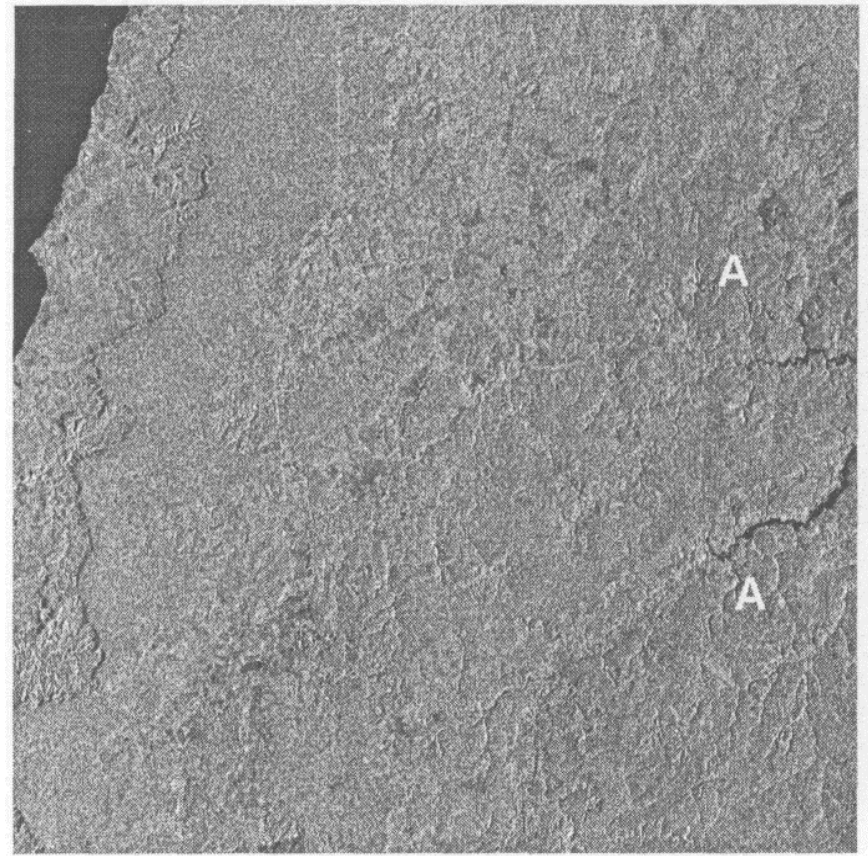

(A)
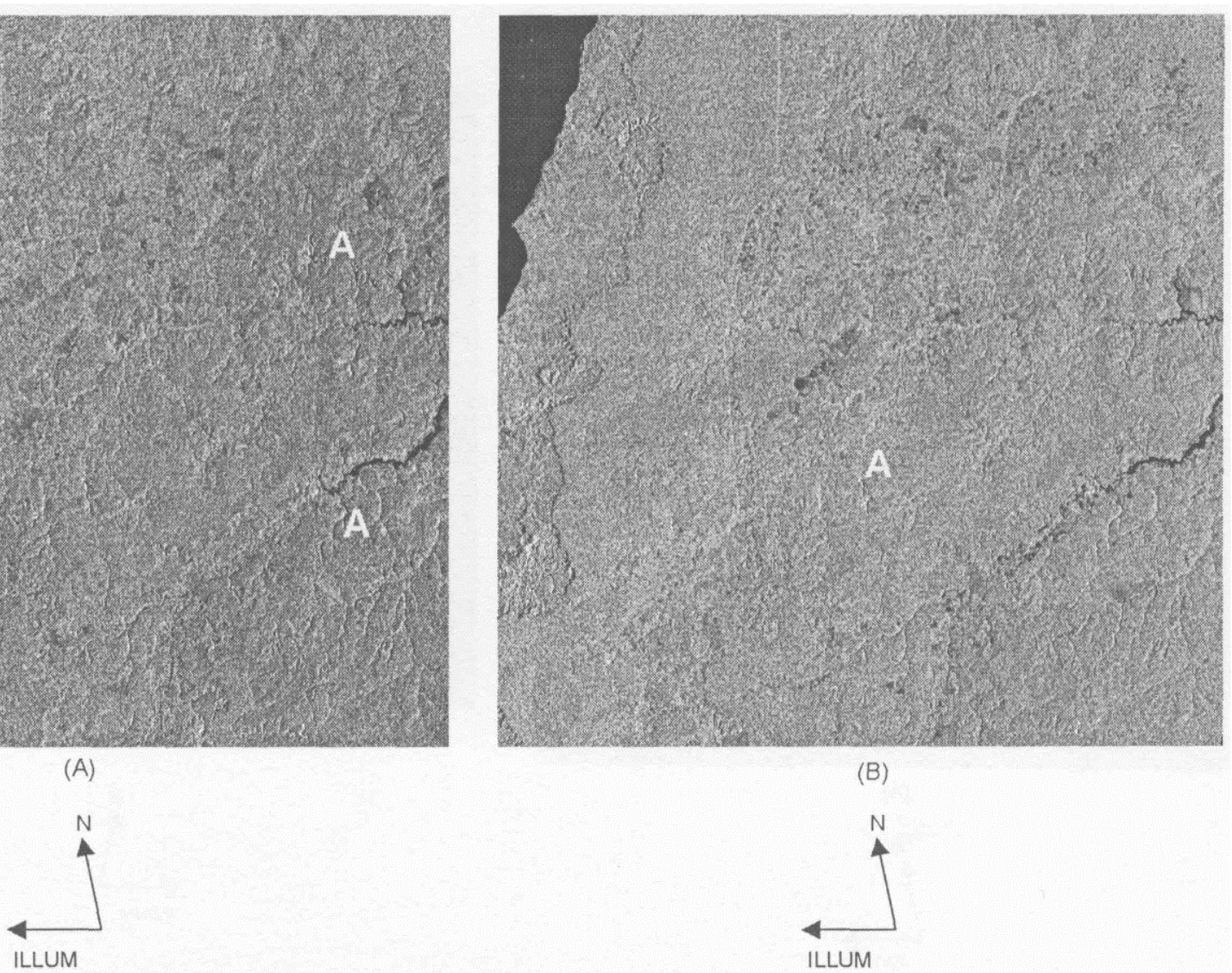

(B)

RADARSAT S5) images. The images were acquired under the same look-azimuth (west looking) and distinct incident angles ( 80 o for the airborne and $35^{\circ}$ for the spaceborne image in the centre of the area). Due to this incidence variation, it is possible to detect with the SAREX image (1) curvilinear and semi-elliptical structures in the interior of the pluton, striking topographically positive with drainages patterns associated (letter A, fig. 5A), and (2) large NW-trending lineaments crossing the area (letter $\mathrm{B}$, fig, 5A) expressed by negative topographic breaks, which cut the batholith and have continuity throughout the country rocks. The features whitin the batholith have been correlated to magmatic zonation fades, while the NW-trending lineaments have been interpreted as fault-line scarps related to the major sinistral Carajás fault system (Paradella et al. 1998). These topographic features were enhanced as radar shadows due to the more suitable incident angle of the airborne radar. On the other hand, due to severe radar shadow in the far range of the SAREX data, RADARSAT presents better viewing geometry for the detection of important features, such as brittle structures (faults) and swarm dikes in the Aguas Claras Formation, and the contact of Grao Para Group with the Xingu Complex (letters A, B, fig. 5B, respectively). With the Landsat TM image (fig. 5C), the overall lack of shadow due to the high Sun elevation in the area (around $40^{\circ}$ ) gives it a flatter appearance, making geological structures difficult to be interpreted. In essence, the side looking aspect of radar coupled with variations in the incident angle provided complementary information for geological mapping in the area. The enhanced topographic patterns within the pluton can be correlated with gamma ray data and field information: (1) high TC responses/more evolved facies (biotite-amphibole syenogranite, biotite syenogranite, biotite monzogranite, letter A, fig. 5D), (2) moderate TC responses/ less evolved facies (amphibole-biotite monzogranite, letter B, fig. 5D), and (3) low TC responses/ probably also associated to lessevolved granites, letter C, fig. 5D).

SAR STEREO The versatility of RADARSAT-1 with data using different beams, allows parallax and radar stereoscopy. A research was also carried out in Carajás with Standard pairs (same-side and

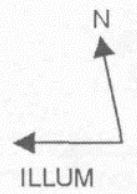

Figure 4. RADARSAT Standard Images from Tapajós National Forest ( $A=$ descending orbit, beam 2; B = descending orbit, beam 7). Letters discussed in the text (RADARSAT images (C) CSA 1996).' 


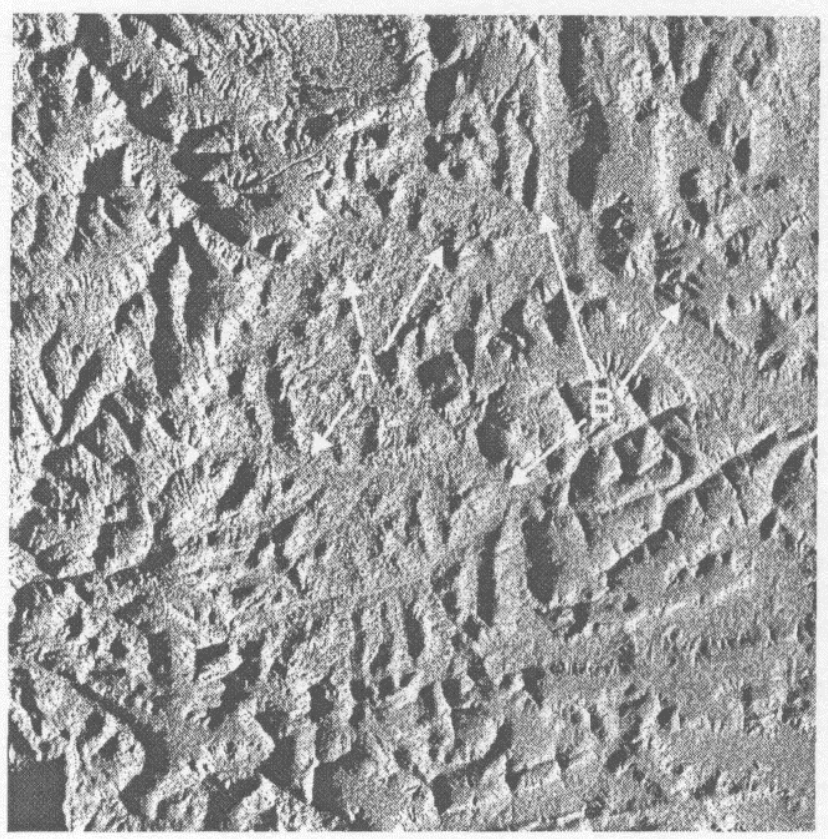

(A)
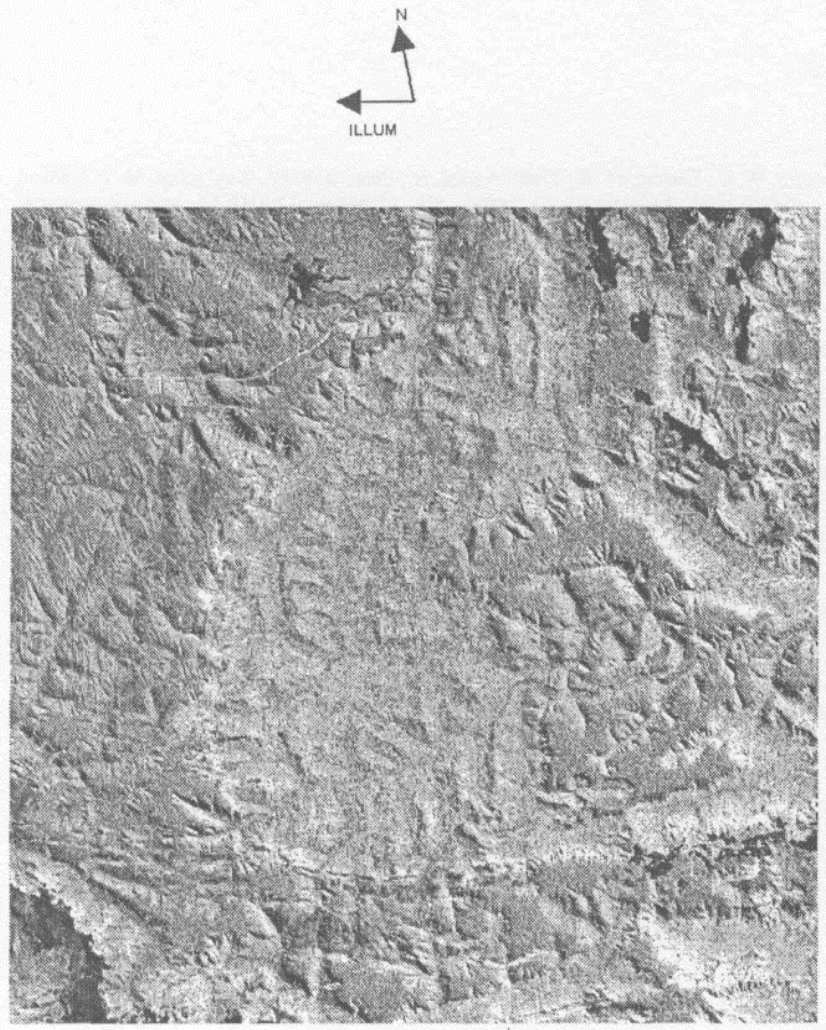

(C)

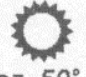

az. $50^{\circ}$

elev. $40^{\circ}$

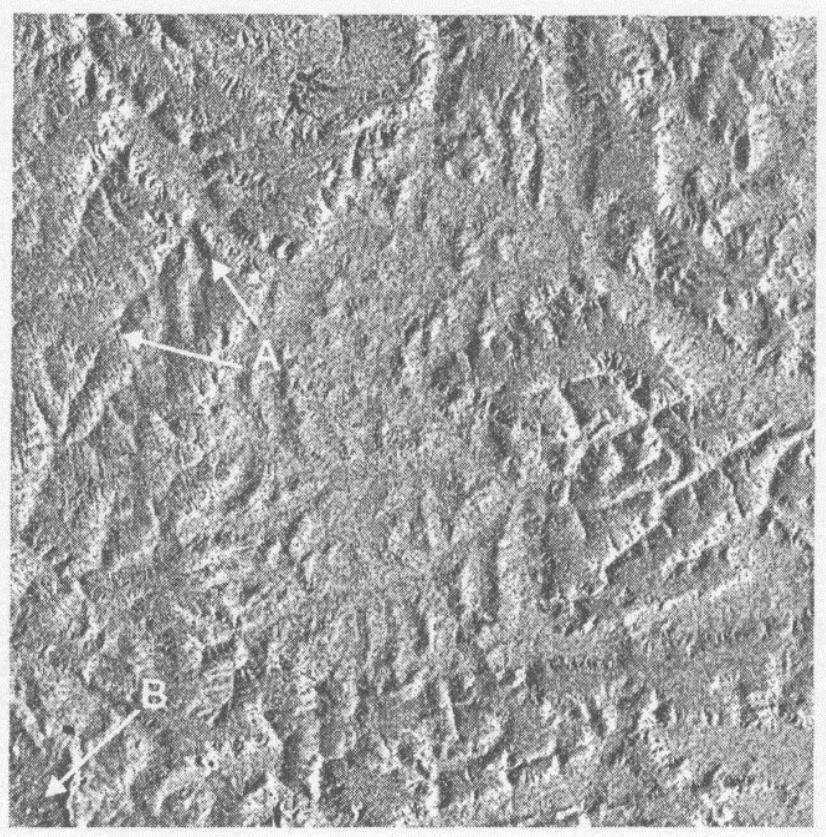

(B)
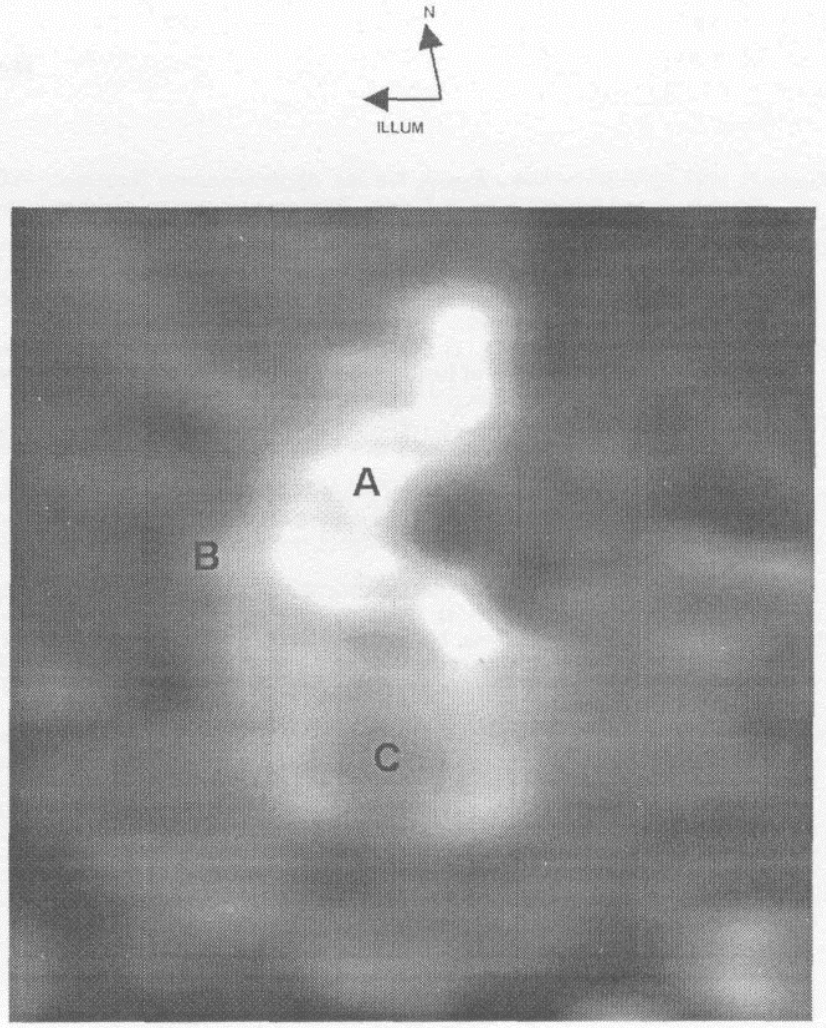

(D)

Figure 5. SAR and ancillary data from the Central Serra dos Carajás Granite area ( $A=$ airborne Wide SAREX, $B=$ Standard Descending RADARSAT, beam 5, C = Lansat TM 4, D = airborne Gamma Total Count image). Letters discussed in the text (RADARSAT image (C) CSA 1996). 
opposite-side) focussing on the geological performance of the radar stereoscopy (Santos et al. 1999). Three types of relief/geology were selected: low relief (gneisses of the Xingu Complex), moderate relief with rolling landscape (Central Granite), and high relief with mountainous surfaces (metavolcanic/metasediments of the Grão Pará Group). The investigation has shown that the use of stereo pair has increased the interpretability of the SAR data when compared to the monoscopic viewing, mainly in the definition of low-angle dipping strata, lithological contacts and general discontinuities. In addition, the extraction of information through the same-side pairs was easier than the opposite-side pairs (some practice was necessary to be comfortable with the opposite-side pairs). However, for areas with moderate relief the best results were obtained from opposite-side stereo due to the vertical exaggeration caused by larger vertical parallax ratio. Finally, the opposite-pairs with steeper viewing geometry have presented the best performance for flat areas due to the enhancement of low local slopes. The difference in price due to the additional images was compensated by the greater information content.

DIGITAL PROCESSING AND INTEGRATION Specific approaches with SAR data need to be applied due to the unique radar viewing geometry and the presence of speckle. In order to correct terrain distortions caused by elevation, ortho-rectification is recommended. Several methodologies have been presented for merging data (Harris et al. 1994). Results from Carajás have confirmed that the IHS transform produces the best performance. Radar integrated with airborne gammaspectrometric data has provided a powerful tool for geological mapping. SAR merged with Landsat TM was sensitive in highlighting structures and geobotanical controls. In addition, RADARS AT-1 descending images were more appropriated for the integration with Landsat TM than the ascending ones. This was caused by (1) a more suitable range of angles, which maximizes enhancements and minimizes attenuations of the terrain features regarding both illumination when using descending images (SAR look azimuth $=278$ o, Sun azimuth around 50-60 o during TM passes in Carajás), and (2) opposite illumination effects on the macrotopography (frontftackslopes) when using ascending SAR with TM, with complex color patterns in the integrated product.

CONCLUSION Distinct SAR systems with different operating configurations provide high quality data for use in the tropics. However, an effective applicability of the technology is only obtained when a consistent background in SAR imagery, digital image processing and photogeologists' skill are taken into account in the application.

Acknowledgments The authors are grateful to dr. Y. E. Shimabukuru (INPE) for providing the Tapajós scenes, and CPRM for the gamma data. The research was funded by FAPESP and CNPq (projects: \# 97/10946-4, \# 300985/90-80). The RADARS AT images were provided by CSA/RSI.

\section{References}

Elachi, C. 1997. Spaceborne Radar Remote Sensing: Applications and Techniques. IEEE Geoscience and Remote Sensing Society. Institute of Electrical and Electronic Engineers Inc., New York, $231 \mathrm{p}$

Ford, J.P., Blom, R.G., Coleman Jr., J.L., Farr, T.G., Plaut, J.J., Pohn, H.A., Sabins Jr., F.F 1998. Radar Geology. In: P.M. Henderson \& A. J. Lewis (eds.). Principles \& Applications of Imaging Ridar, Manual of Remote Sensing, New York, Am. Soc. Phot, and Rem. Sens., 511-565.

Harris, J.R., Bowie, C., Rencz, A. N., Graham, D. 1994. Computer-Enhancement Techniques for the Integration of Remotely Sensed, Geophysical, and Thematic Data for the Geosciences. Canadian Journal of Remote Sensing, 20 (3): 210-221.

JPL (Jet Propulsion Lab) 1980. Radar Geology: An Assessment. Jet Propulsion Lab, Rept. of the Radar Geology Workshop, Snowmass Colorado, NASA, JPL Publication 8061.

Lewis, A. J., Henderson, P.M., Holcomb, D.W. 1998. Radar Fundamentals: The Geoscience Perspective. In: P.M. Henderson \& A. J. Lewis (eds.). Principles \& Applications of Imaging Radar, Manual of Remote Sensing, New York, Am. Soc. Phot, and Rem. Sens., 131-181.

Lowman Jr., P. 1994. Radar Geology of the Canadian Shield: a 10-Year Review. Canadian Journal of Remote Sensing, 20 (3): 198- 209.

Paradella, W. R., Silva, M.F.F., Rosa, N. A., Kushigbor, C.A. 1994. A geobotanical approach to the tropical rainforest environment of the Carajás Mineral Province (Amazon Region, Brazil). International Journal of Remote Sensing, 15 (8): 16331648 .

Paradella, W. R., Bionelli, P. A Veneziani, P., Pietsch, R. W. Toutin, T. 1997. Airborne and spaceborne Synthetic Aperture Radar (SAR) integration with Landsat TM and gamma ray spectrometry for geological mapping in a tropical rainforest environment, (7): 1483-1501
Paradella, W. R., Santos, A. R., Dall" Agnol, R., Pietsch, R.W., San'Anna, M.V. 1998. A Geological Investigation Based on Airborne (SAREX) and Spaceborne (RADARSAT-1) SAR Integrated Products in the Central Serra dos Carajás Granite Area, Brazil, Canadian Journal of Remote Sensing, 21 (4): 376-392.

Paradella, W. R. Santos, A. R., Veneziani, P., Sant'Anna, M. V, Morais, M. C. 2000 Geological Investigation Using RADARS AT-1 Images in the Tropical Rain Forest Environment of Brazil, Canadian Journal of Remote Sensing, 26 (2): 81-87.

Pinheiro, R. V. L. 1997. Reactivation history of the Carajás and Cinzento Strike-Slip Systems, Amazon Brazil, University of Durham, UK., Ph. D. Dissertation, 408 p.

Santos, A. R., Paradella, W. R., Veneziani, P., Morais, M. C. 1999. A Estereoscopia com Imagens RADARS AT-1: Uma Avaliajao Geoldgica na Provincia Mineral de Carajás. Brazilian Journal of Geoscience, 29 (4), in press.

Shimabukuru, Y. E., Amaral, S., Ahern, F.J., Pietsch, R. W. 1998. Land Cover Classification from RADARSAT data of the Tapaj6s National Forest, Brazil. Canadian Journal of Remote Sensing, 24 (4): 393-401.

Singhroy, V. H. \& Saint-Jean, R. 1999. Effects of Relief on the Selection of RADARSATIncidence Angle for Geological Applications, Canadian Journal of Remote Sensing 25 (3): 211-217.

Torres, R.B. 1998. Contribuição ao estudo do arcabouco estrutural da area do Rio fia, geologia, magnetometria, gravimetria e sensoriamento remoto. Dissertação de Mestrado, INPE 152 .

Van der Sanden, J. J.I 997. Radar remote sensing to support tropical forest management. Tropenbos-Guyana Series 5, Georgetown, Guyana, 330.p.

Contribution IGC-089

Submitted February 25, 2000 Accepted for publication April 27, 2000 Tapajós, Bacia do Amazonas, atraves da integrafdo digital de dados de topogra- 